\title{
RULES GENERATION UNTUK KLASIFIKASI DATA BAKAT DAN MINAT BERDASARKAN RUMPUN ILMU DENGAN DECISION TREE
}

\author{
Suryadi Syamsu ${ }^{1}$, Muhajirin ${ }^{2}$, Nyoman Suta Wijaya ${ }^{3}$ \\ Teknik Informatika, STMIK AKBA ${ }^{1,2,3}$ \\ Email : adi@akba.ac.id ${ }^{1}$, aji@akba.ac.id ${ }^{2}$,nyoman.nsw95@gmail.com ${ }^{3}$
}

\begin{abstract}
ABSTRAK
Penelitian ini bertujuan untuk merancang aplikasi dan mengimplementasikan Rules Generation untuk klasifikasi data bakat dan minat berdasarkan rumpun ilmu dengan decision tree. Data ini diperoleh melalui penelitian dalam bentuk kuesioner pada objek penelitian dan pustaka. Data dianalisa dengan data bakat dan minat yang berasal dari ilmu psikologi ialah Tes IST (Intelligenz Struktur Test) merupakan salah satu tes psikologi untuk mengukur tingkat intelegensi seseorang. Data - data dari tes IST tersebut diolah bersama data rumpun ilmu (bidang studi perguruan tinggi) dan diterjemahkan dalam ilmu data mining dengan menganalisa menggunakan pohon keputusan (decision tree). Perancangan aplikasi data bakat dan minat dirancang menggunakan bahasa pemrograman PHP dengan tampilan antarmuka web. Hasil penelitian ini menunjukkan bahwa Implementasi Rules Generation terhadap Decision Tree $(R G F D T)$ penelitian tentang penentuan jurusan seseorang yang menggunakan algoritma $\mathrm{C} 4.5$ dapat mengatasi cabang-cabang pohon keputusan yang tidak relevan menjadi relevan, sehingga dalam mengimplementasi ke dalam bahasa pemrograman dapat lebih mudah diterjemahkan., dan aplikasi tes bakat dan minat dapat berjalan dengan baik dan memudahkan responden dalam melakukan tes bakat dan minat dengan mudah.
\end{abstract}

Kata Kunci: RGFDT, Rumpun Ilmu, Bakat, Minat, Decision Tree.

\begin{abstract}
This study aims to design applications and implement Rules Generation to classify talent data and interest based on science clusters with the decision tree. This data was obtained through research in the form of a questionnaire on the object of research and data library analyzed with talent and interest data derived from psychology is the IST Test (Intelligenz Structure Test) is a psychological test to measure the level of one's intelligence. Data from the IST test are processed together with knowledge clusters (college study fields) and translated in data mining science by analyzing using decision trees (decision trees). Designing talent and interest data applications is designed using the PHP programming language with a web interface. The results of this study indicate that the implementation of the Rules Generation on Decision Tree (RGFDT) research on determining the subject of someone who uses the C4.5 algorithm can overcome the branches of decision trees that are not relevant to be relevant, so that implementing them into programming languages can be more easily translated, and applications aptitude tests and interests can work well and make it easy for respondents to test their talents and interests easily.
\end{abstract}

Keywords: RGFDT, Clump of Science, Talent, Interest, Decision Tree. 


\section{PENDAhuluaN}

Berkembangnya teknologi informasi saat ini berdampak luas ke semua bidang ilmu pengetahuan, termasuk bidang ilmu psikologi dan ilmu komputer yang dalam hal ini berdasarkan data bakat dan minat seseorang meningkatkan sumber daya manusia melalui pendidikan.

$\begin{array}{cr}\text { Penulis } & \text { bertujuan } \\ \text { mengkolaborasikan antara aplikasi }\end{array}$
analisa bakat dan minat (ilmu komputer) dengan ilmu psikologi dari berbagai masalah yang sering menghadapi kondisi mahasiswa sulit untuk mencapai prestasi yang maksimal. Lemahnya pemahaman dan logika penalaran, tidak tercapainya prestasi belajar, minder, kurang pergaulan, sulit mendapat pekerjaan setelah lulus kuliah menjadi masalah yang dihadapi.

Ternyata kesimpulan tersebut terlalu dini, setiap manusia memiliki bakat. Bakat merupakan potensi. Bakat yang dimiliki merupakan potensi yang perlu dikembangkan atau dilatih agar dapat mencapai prestasi. Menurut Monk (dalam Terriavini, et.al. 2016), menjelaskan bahwa keberbakatan adalah suatu potensi bawaan yang memerlukan binaan guna mencapai prestasi sesuai dengan prestasinya. Lanjut menurut Kartono (dalam Terttiavini, et.al 2016), menyatakan bahwa bakat adalah potensi atau kemampuan kalau diberikan kesempatan untuk dikembangkan melalui belajar akan menjadi kecakapan yang nyata. Dari pernyaatan para ahli tersebut maka dapat diambil kesimpulan bahwa memilih jurusan yang tepat berdasarkan bakat seseorang akan menjadikan seseorang dapat mencapai prestasi yang maksimal dan dapat mengembangkan potensi yang dimiliki.

Ada masalah lain yang muncul adalah tidak semua orang menget: bakatnya, untuk mengetahui pot bakat seseorang tidaklah mudah karena ada perbedaan mendasar antara bakat dan minat. Minat sering diartikan sebagai bakat, padahal minat bukanlah bakat. Minat sangat dipengaruhi oleh lingkungan sekitar keluarga ataupun teman dan masyarakat, sementara bakat adalah kemampuan seseorang yang didapatkan sejak lahir. Oleh karena itu, perlu bantuan ahli psikologi untuk mengetahui bakat seseorang. Namun tes bakat yang menggunakan jasa ahli psikologi tidaklah gratis dan semakin rinci ingin mengetahui bakat yang dimiliki maka biayanya akan semakin mahal. Masalah inilah yang dicarikan solusi sehingga timbul gagasan dari penulis untuk membangun aplikasi analisa bakat dalam menentukan jurusan.

Aplikasi ini dibangun dengan teknik pohon keputusan (decision tree), decison tree yang dipakai dalam penelitian ini menggunakan metode pengembangan decision tree yang baru yaitu menurut Al-Hegami dan Sultan (dalam Oktavia, et al., 2105), RGFDT (Rules Generation From the Decision Tree) untuk membangun general rules dari rule set yang dihasilkan dari algoritma C4.5. Algoritma C4.5 merupakan metode berbasis pohon 
keputusan, atribut dilakukan dengan menggunakan Gain, Ratio, dengan mencari nilai Entropy. Algoritma C4.5 sendiri menggunakan pendekatan induksi dimana dalam pendekatan ini, algoritma C4.5. Membagi data berdasarkan kriteria yang dipilih untuk membuat sebuah pohon keputusan yang menggunakan pendekatan secara topdown.

Beberapa penelitian terkait yang menggunakan metode decision tree algoritma $\mathrm{C} 4.5$ maupun pengembangan decision tree metode RGFDT (Rules Generation From Decison Tree) adalah aplikasi Sistem Pakar Penentu Bidang Studi Di Tingkat Perguruan Tinggi Berbasis Web (Terttiavini, et.al, 2016). Penelitian kedua tentang Analisis Kinerja Algoritma C4.5 Pada Sistem Pendukung Keputusan Penentuan Jenis Pelatihan (Oktavia, et al. 2015).

Berdasarkan uraian di atas maka dalam penelitian ini akan meneliti siswa dan siswi di SMA Negeri 1 Bantaeng dan menggunakan metode algoritma C4.5 yang terbaru, dalam hal ini memberikan saran pilihan siswa (calon mahasiswa) untuk memilih jurusan yang tepat di perguruan tinggi, yaitu menggunakan metode RGFDT (Rules Generation From the Decision Tree) dengan judul penelitian "Rules Generation Untuk Klasifikasi Data Bakat dan Minat Berdasarkan Rumpun Ilmu Dengan Decision Tree".

\section{LANDASAN TEORI}

\subsection{RGFDT (Rules Generation From the} Decision Tree)

Menurut Oktavia, et al., (2015), menjelaskan bahwa RGFDT (Rules
Generation From the Decision Tree) merupakan sebuah algoritma yang efisien untuk mengkonversi pohon keputusan untuk seperangkat aturan tanpa kondisi yang tidak relevan.

Menurut Chang, Ding-An, et.al (2001), menjelaskan bahwa algoritma RGFDT dapat menghapus semua nilai-nilai yang tidak relevan dari sebuah pohon keputusan. Algoritma yang diterapkan (RGFDT) untuk menghilangkan nilai-nilai yang tidak relevan selama proses konversi pohon keputusan untuk sesuai aturan dengan semantik dari pohon keputusan, sehingga kondisi yang tidak relevan tidak akan muncul dalam aturan yang dihasilkan.

Penjelasan di atas tentang Rules Generation From the Decision Tree dapat ditarik sebuah kesimpulan bahwa $R G F D T$ adalah sebuah algoritma yang efisien dalam mengkonversi pohon keputusan tanpa kondisi yang tidak relevan yang sesuai dengan semantik dari pohon keputusan.

\subsection{Klasifikasi Data}

Menurut Gorunescu (dalam Andriani, 2012) memaparkan tentang klasifikasi (taksonomi) merupakan proses menempatkan suatu objek atau konsep ke dalam satu set kategori berdasarkan objek atau konsep yang bersangkutan.

Definisi tentang klasifikasi juga dijelaskan oleh Larose dalam (Chair, Nasution dan Rizki, 2017), menjelaskan bahwa klasifikasi merupakan pengelompokan sampel berdasarkan ciri-ciri persamaan dan perbedaan dengan menggunakan variabel target sebagai kategori. Ada beberapa macam pengklasifikasian dalam data mining yaitu decision tree, naive bayes, svm, dan lain-lain. 
Beberapa pernyataan di atas dapat disimpulkan bahwa klasifikasi data adalah menempatkan suatu objek atau konsep ke dalam pengelompokan beberapa sampel data berdasarkan ciriciri persamaan dan perbedaan dengan menggunakan variabel.

\subsection{Rumpun Ilmu}

Sesuai Peraturan Menteri

Pendidikan dan Kebudayaan Republik Indonesia dengan nomor: 0404/E3.2/2015, tahun 2015, perihal: Rumpun Ilmu Pengetahuan dan Teknologi serta Gelar Lulusan Perguruan Tinggi.

Rumpun ilmu adalah sekumpulan rumpun dan dan sub rumpun ilmu serta bidang ilmu dalam sebuah rumpun. Misalnya, Rumpun Ilmu Teknik, Sub Rumpun Ilmu di dalamnya ialah Sub Rumpun Teknik Sipil dan Perancangan Tata Ruang, Sub Rumpun Ilmu Keteknikan Industri, Sub Rumpun Ilmu Teknik Elektro dan Informatika, dan lain sebagainya.

\subsection{Decison Tree (Pohon Keputusan) dan Agoritma $\mathbf{C 4 . 5}$}

Definisi Decision tree Yudha (2015), menjelaskan bahwa Decision Tree merupakan salah satu metode klasifikasi pada text mining. Kelebihan dan kekurangan dari decision tree sebagai berikut.

Kelebihan dari metode pohon keputusan (Decision Tree) adalah:

a. Daerah pengambilan keputusan yang sebelumnya kompleks dan sangat global, dapat diubah menjadi lebih simpel dan spesifik.

b. Eliminasi perhitungan-perhitungan yang tidak diperlukan, karena ketika menggunakan metode pohon keputusan maka sample diuji hanya berdasarkan kriteria atau kelas tertentu.

c. Fleksibel untuk memilih fitur dari internal node yang berbeda, fitur yang terpilih akan membedakan suatu kriteria dibandingkan kriteria yang lain dalam node yang sama. Kefleksibelan metode pohon keputusan ini meningkatkan kualitas keputusan yang dihasilkan jika dibandingkan ketika menggunakan metode penghitungan satu tahap yang lebih konvensional

Dalam analisis multivariat, dengan kriteria dan kelas yang jumlahnya sangat banyak, seorang penguji biasanya perlu untuk mengestimasikan baik itu distribusi dimensi tinggi ataupun parameter tertentu dari distribusi kelas tersebut. Metode pohon keputusan dapat menghindari munculnya permasalahan ini dengan menggunakan criteria yang jumlahnya lebih sedikit pada setiap node internal tanpa banyak mengurangi kualitas keputusan yang dihasilkan.

Kekurangan dari metode pohon keputusan (Decision Tree) adalah:

a. Terjadi overlap terutama ketika kelas-kelas dan kriteria yang digunakan jumlahnya sangat banyak. Hal tersebut juga dapat menyebabkan meningkatnya waktu pengambilan keputusan dan jumlah memori yang diperlukan.

b. Pengakumulasian jumlah error dari setiap tingkat dalam sebuah pohon keputusan yang besar.

c. Kesulitan dalam mendesain pohon keputusan yang optimal.

d. Hasil kualitas keputusan yang didapatkan dari metode pohon keputusan sangat tergantung pada bagaimana pohon tersebut didesain.

Menurut Ina (2013), mengatakan bahwa algoritma C4.5 merupakan 
algoritma yang digunakan untuk membentuk pohon keputusan. Algoritma ini merupakan metode klasifikasi dan prediksi yang sangat kuat dan terkenal. Menurut Rahmayani (2014), mengatakan bahwa algoritma C4.5 merupakan algoritma yang digunakan untuk membangun sebuah pohon keputusan (decision tree) dari data.

Menurut Oktavia (2015), menjelaskan ulang berdasarkan analisa yang dilakukan Jose Augusto dalam penelitiannya bahwa, algoritma C4.5 mampu memberikan hasil yang efektif dalam mendukung suatu keputusan dengan kriteria yang dibuat secara random. Selain itu, alasan pemilihan algoritma $\mathrm{C} 4.5$ adalah, algoritma tersebut mampu menghasilkan sub sistem model base yang dapat digunakan untuk menunjang sistem pendukung keputusan.

Tabel 1. Contoh Kasus Keputusan Bermain Tenis

\begin{tabular}{|c|l|l|l|l|l|}
\hline NO & OUTLOOK & TEMPERATURE & HUMIDITY & WINDY & PLAY \\
\hline 1 & Sunny & Hot & High & False & No \\
\hline 2 & Sunny & Hot & High & True & No \\
\hline 3 & Cloudy & Hot & High & False & Yes \\
\hline 4 & Rainy & Mild & High & False & Yes \\
\hline 5 & Rainy & Cool & Normal & False & Yes \\
\hline 6 & Rainy & Cool & Normal & True & Yes \\
\hline 7 & Cloudy & Cool & Normal & True & Yes \\
\hline 8 & Sunny & Mild & High & False & No \\
\hline 9 & Sunny & Cool & Normal & False & Yes \\
\hline 10 & Rainy & Mild & Normal & False & Yes \\
\hline 11 & Sunny & Mild & Normal & True & Yes \\
\hline 12 & Cloudy & Mild & High & True & Yes \\
\hline 13 & Cloudy & Hot & Normal & False & Yes \\
\hline 14 & Rainy & Mild & High & True & No \\
\hline
\end{tabular}

Dalam kasus yang tertera pada tabel 1, akan dibuat pohon keputusan untuk menentukan main tenis atau tidak dengan melihat keadaan cuaca, temperatur, kelembaban dan keadaan angin.

Berikut ini adalah penjelasan lebih rinci mengenai masing-masing langkah dalam pembentukan pohon keputusan dengan menggunakan algoritma C4.5 untuk menyelesaikan permasalahan pada Tabel 3.8.

a. Menghitung jumlah kasus, jumlah kasus untuk keputusan Yes, jumlah kasus untuk keputusan No, dan Entropy dari semua kasus dan kasus yang dibagi berdasarkan atribut OUTLOOK, TEMPERATURE, HUMIDITY dan WINDY. Setelah itu lakukan penghitungan Gain untuk masing- masing atribut. 
Dari hasil tersebut dapat digambarkan pohon keputusan sementara-nya tampak seperti pada gambar 1. berikut.

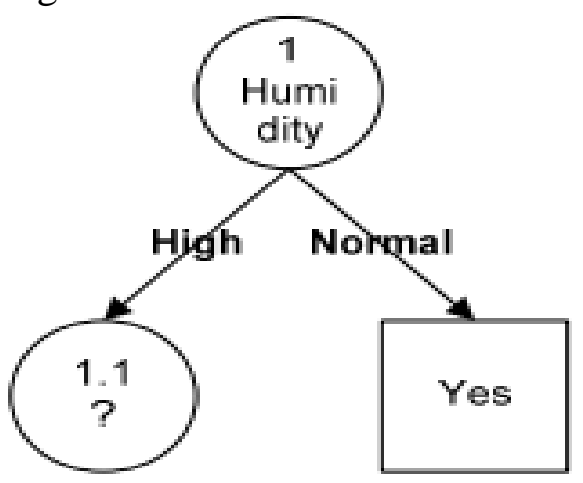

Gambar 1. Pohon Keputusan Hasil Perhitungan Node 1

b. Menghitung jumlah kasus, jumlah kasus untuk keputusan Yes, jumlah kasus untuk keputusan No, dan Entropy dari semua kasus dan kasus yang dibagi berdasarkan atribut Outlook, Temperature, dan Windy yang dapat menjadi node akar dari nilai atribut High. Setelah itu lakukan penghitungan Gain untuk masing-masing atribut.

Pohon keputusan yang terbentuk sampai tahap ini ditunjukkan pada gambar 2. berikut:

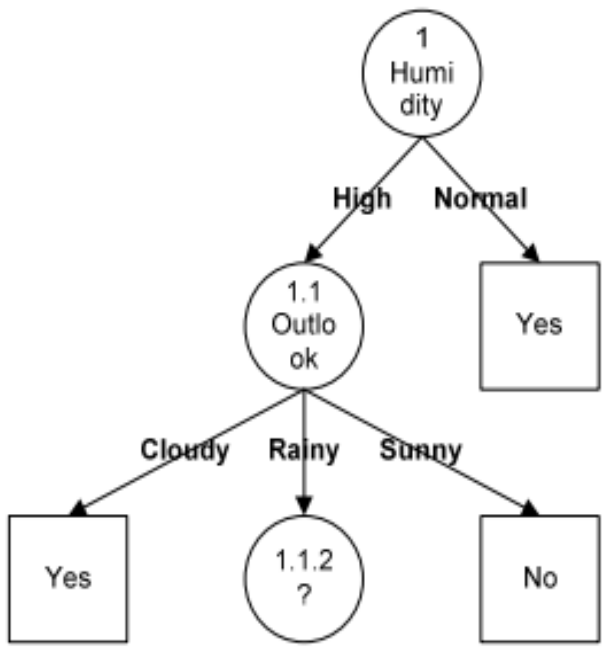

Gambar 2. Pohon Keputusan Hasil Perhitungan Node 1.1 c. Menghitung jumlah kasus, jumlah kasus untuk keputusan Yes, jumlah kasus untuk keputusan No, dan Entropy dari semua kasus dan kasus yang dibagi berdasarkan atribut TEMPERATURE dan WINDY yang dapat menjadi node cabang dari nilai atribut RAINY. Setelah itu lakukan penghitungan Gain untuk masing-masing atribut.

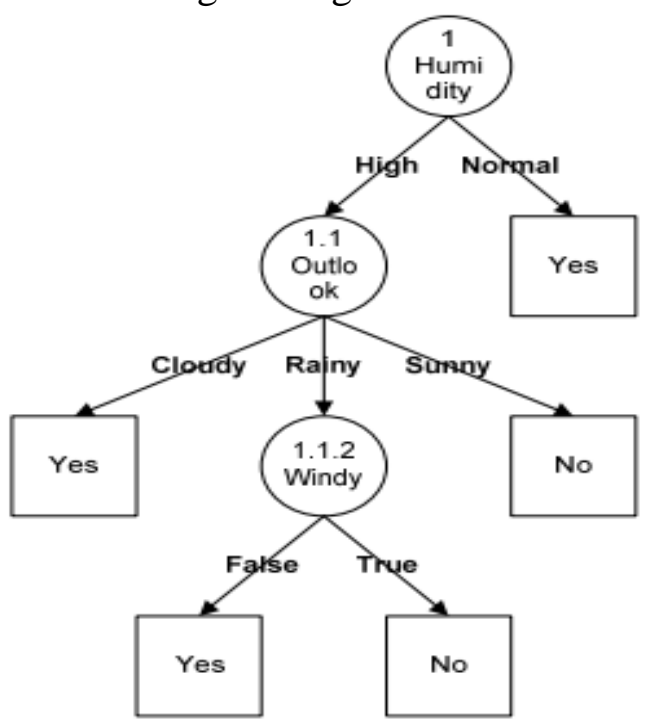

\section{Gambar 3. Pohon Keputusan Hasil Perhitungan Node 1.1.2}

Pohon keputusan yang terbentuk sampai tahap ini ditunjukkan pada gambar 3. Dengan memperhatikan pohon keputusan pada gambar 3, diketahui bahwa semua kasus sudah masuk dalam kelas. Dengan demikian, pohon keputusan pada gambar 2.5 merupakan pohon keputusan terakhir yang terbentuk.

\subsection{Rumus IQ Deviasi}

Untuk mengukur IQ berdasarkan tes yang dilakukan menggunakan rumus IQ Deviasi. Rumus deviasi diciptakan oleh Davis Wechsler. IQ tdihitung berdasarkan perbandingan norma kelompok (Mean) dan dinyatakan dalam besarnya penyimpangan (deviasi standar) dari 
norma kelompok tersebut. Dalam statistika, angka yang dinyatakan dalam satuan deviasi standar disebut skor standar dengan rumus :

Skor standar $=\mathrm{m}+\mathrm{s}[(\mathrm{X}-\mathrm{M}) / \mathrm{Sx}]$

Dimana :

$$
\begin{aligned}
& \mathrm{m}: \text { mean } \\
& \mathrm{s}: \text { deviasi standar } \\
& \mathrm{X}: \text { skor mentah yang akan } \\
& \text { dikonversikan } \\
& \mathrm{M}: \text { mean distribusi skor } \\
& \mathrm{Sx}: \text { Deviasi standar }
\end{aligned}
$$

Mean yang ditetapkan oleh wechsler adalah 100. Nilai tersebut dimabil untuk melestarikan kebiasaan tradisional menafsirkan IQ sebesar 100 sebagai tingkat intelegensi normal. Nilai Deviasi standar adalah 15 (yang diperoleh dari tes intelegensi.

\subsection{Psikologi dan Psikometri}

Psikologi merupakan sebuah disiplin ilmu dan terapan yang mempelajari mental dan perilaku secara ilmiah. Psikologi memiliki tujuan untuk memahami individu dan kelompok dengan memperhatikan prinsip pribadi dan meneliti kasis spesifik.

Menurut Saifuddin dalam jurnal Terttiavini, et.al. (2014) menjelaskan bahwa, psikometri adalah ilmu tentang teori pengukuran psikologis. Ruang lingkup psikometri adalah masalah pengembangan teori dan model tes serta pengembangan dasar-dasar evaluasi terhadap kualitas tes. Pada tahap apilikasinya, teori psikometri memberikan landasan fundamental dalam perancangan dan pengembangan tes psikologis sehingga metode-metode konstruksi tes berkembang maju dan dapat menghasilkan berbagai bentuk tes psikologi yang valid dan reliabel.

\subsection{Bakat dan Minat}

Menurut Terttiaavini, et al. (2016), mengatakan bahwa bakat (aptitude) merupakan potensi (potensial ability). Bakat yang dimiliki merupakan potensi yang perlu dikembangkan atau dilatih agar dapat mencapai prestasi. Lanjut lagi oleh Monk dalam (Terttiaavini, et al. 2016), menambahkan bahwa keberbakatan (Giftedness) adalah suatu potensi bawaan yang memerlukan binaan guna mencapai prestasi sesuai dengan prestasinya.

Kesimpulan dari penjelasan di atas adalah bahwa bakat dan minat seseorang akan menjadikan seseorang dapat mencapai prestasi yang maksimal

\section{METODE}

Rules Generation (RGFDT) adalah metode pengembangan dari algoritma $C 4.5$, dijelaskan oleh Oktavia, et al., (2015) menjelaskan bahwa RGFDT (Rules Generation From the Decision Tree) merupakan sebuah algoritma yang efisien untuk mengkonversi pohon keputusan untuk seperangkat aturan tanpa kondisi yang tidak relevan. Penulis dalam hal ini mengkolaborasikan antara ilmu psikologi dengan ilmu komputer menggunakan teknik pohon keputusan (decision tree), decison tree yang dipakai dalam penelitian ini menggunakan metode pengembangan decision tree yang baru yaitu menurut AlHegami dan Sultan dalam (Oktavia, et al., 2105).

Jadi, dalam penelitian ini akan menghasilkan sebuah sistem aplikasi tes psikologi (bakat) dalam memberikan saran jurusan kepada siswa (calon mahasiswa) sesuai nilai dari tes psikologi tersebut, 
sehingga siswa (calon mahasiswa) tidak salah pilih jurusan saat melanjutkan pendidikannya di perguruan tinggi yang akan dituju.

Pohon Keputusan digunakan untuk memetakan beberapa alternatif pemecahan masalah dari masalah-masalah yang dihadapi pohon keputusan dapat menunjukkan faktor-faktor kemungkinan / probabilitas yang memengaruhi alternatif tersebut disertai estimasi hasil akhir yang dapat digunakan untuk pengambilan keputusan.

Pada penelitian ini akan menunjukkan perubahan rules (aturan-aturan) dalam pohon keputusan algoritma $\mathrm{C} 4.5$ yang akan mengefisienkan dalam hal mengkonversi pohon keputusan untuk seperangkat aturan tanpa kondisi yang tidak relevan. Dapat juga dikatakan tidak akan mengubah hasil dari pohon keputusannya namun hanya mengubah aturan percabangannya agar lebih efisien.

1) Pohon Keputusan Algoritma $\mathrm{C} 4.5$

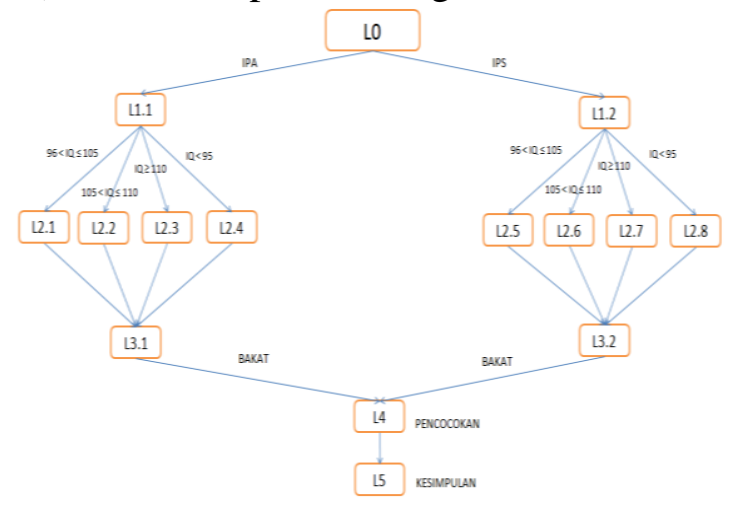

Gambar 4. Pohon Keputusan Algoritma C4.5

Pada Gambar 4. menunjukkan tampilan pohon keputusan algoritma C4.5. Pada gambar tersebut menampilkan kodekode L0, L1.1, L1.2, L2.1 dan seterusnya, L3.1, L3.2, L4 dan kode L5 yang berarti aturan-aturan (rules based). Rule Based yaitu sistem yang berdasarkan aturanaturan untuk memecahkan masalah. Setiap simpul pohon keputusan akan membandingkan nilai dengan aturan yang telah ditetapkan.

2) Pengembangan Metode Pohon Keputusan Dari Algoritma C4.5 dengan Metode RGFDT (Rules Generation from the Decision Tree)

Sebelum melanjutkan ke tahap selanjutnya yaitu pohon keputusan RGFDT hasil konversi dari algoritma C4.5, proses selanjutnya adalah cara menkonversi aturan-aturan percabangan pada pohon keputusan pada Gambar 3.3.

Adapun algoritma dari RGFDT adalah sebagai berikut.

a) Input : Pohon Keputusan

b) Let Branch = $\{$ Branch1,...,BranchN $\}$;

c) For each branch Branch' in Branch Do

d) Output : Rules tanpa kondisi yang tidak relevan

Berikut ini merupakan flowchart dari RGFDT dapat dilihat pada Gambar 3.4.

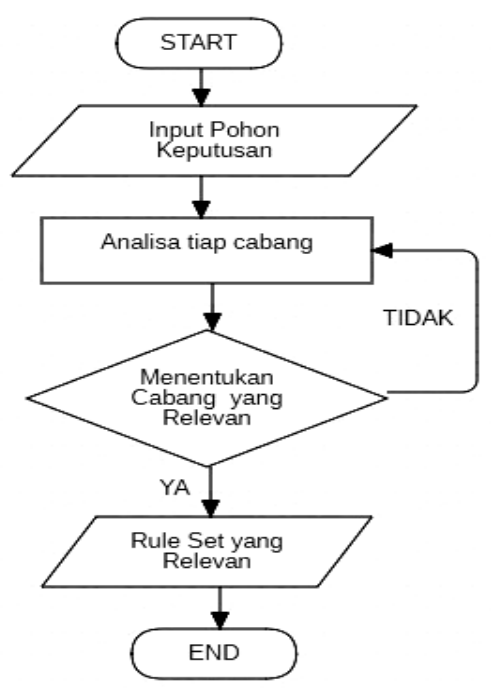

Gambar 5. Flowchart RGFDT 
Flowchart Gambar 5. merupakan alur dari metode RGFDT. Input berupa pohon keputusan selanjutnya dilakukan analisa tiap cabang, apabila terdapat kondisi yang tidak relevan maka akan dilakukan pemangkasan cabang. Sehingga menghasilkan rules baru tanpa kondisi yang tidak relevan.

Untuk mengimplementasikan RGFDT menggunakan algoritma C4.5 dibutuhkan Perancangan Basis Data atau Class Diagram seperti gambar 6.

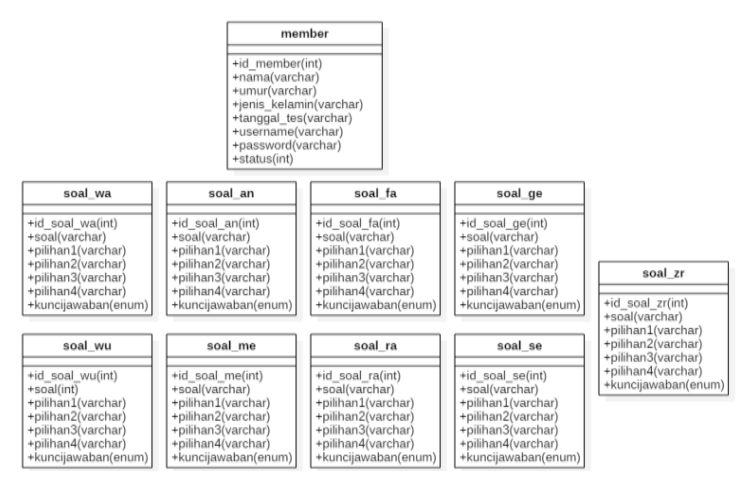

Untuk perancangan Interface atau antar muka aplikasi dibuat menggunakan bahasa pemrograman PHP seperti terlihat pada gambar 7 .

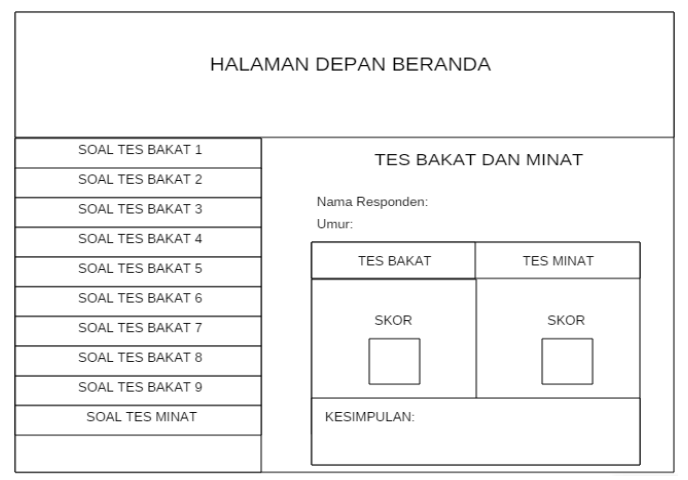

Gambar 7. Interface / Antarmuka Aplikasi

\section{HASIL DAN PEMBAHASAN}

Tampilan antarmuka dan petunjuk pemakaian dari aplikasi Tes Minat dan Bakat. a. Halaman Admin.

1) Halaman LOGIN

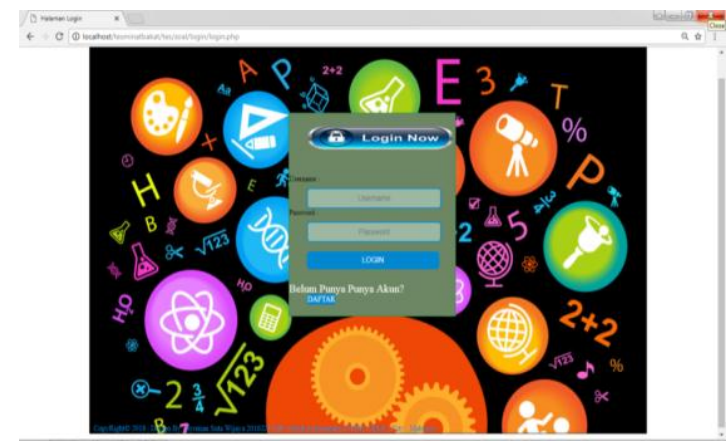

Gambar 8. Halaman Login

Petunjuk Penggunaan Gambar 8.:

a) Mengakses Link Login pada browser;

b) Sistem aplikasi menampilkan halaman login;

Input username dan password, lalu klik tombol LOGIN untuk masuk sebagai ADMIN atau sebagai USER biasa.

1) Halaman User, Tes Minat dan Bakat.

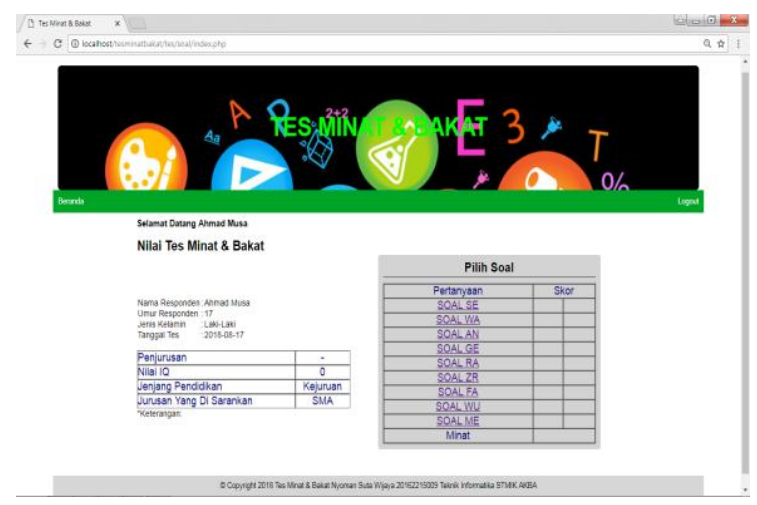

\section{Gambar 9. Halaman Beranda Tes} Minat dan Bakat

Petunjukkan penggunaan Gambar 9.:

a) Mengakses Halaman User;

b) Klik tombol MULAI TES;

c) Sistem akan menampilkan halaman Tes Minat; 
d) Ceklis atau pilih 3 jurusan yang anda minati lalu klik tombol MASUKKAN JAWABAN;

e) Sistem akan menampilkan pilihan anda, dan setelah itu anda mengklik tombol kembali, sistem akan menampilkan halaman Tes Minat dan Bakat.

f) Setelah dari halaman Tes Minat, sistem akan menampilkan halaman beranda Tes Minat dan Bakat. Terdiri dari identitas anda sebagai responden, tabel nilai dari setiap tes soal, dan tabel hasil dari semua nilai soal dan tes minat yaitu penjurusan, nilai iq, jenjang D1, D3, S1, S2 atau S3, dan saran jurusan.

2) Halaman User, Halaman Tes Soal Teks

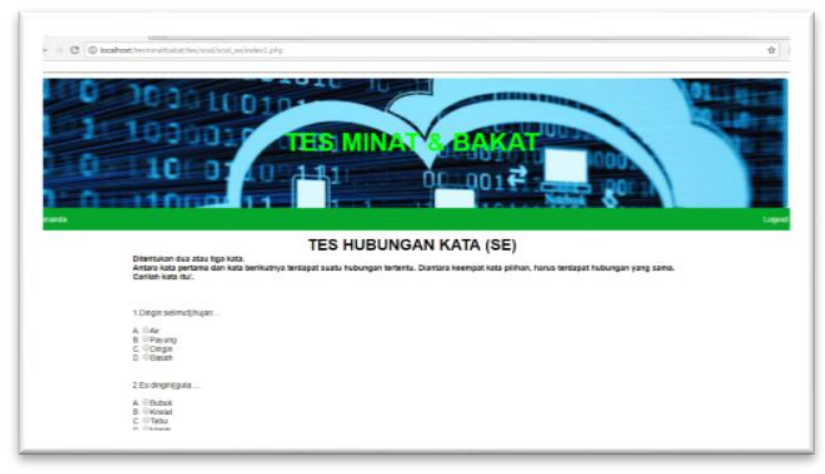

\section{Gambar 10. Halaman Tes Soal Teks}

3) Halaman User, Tes Soal Gambar

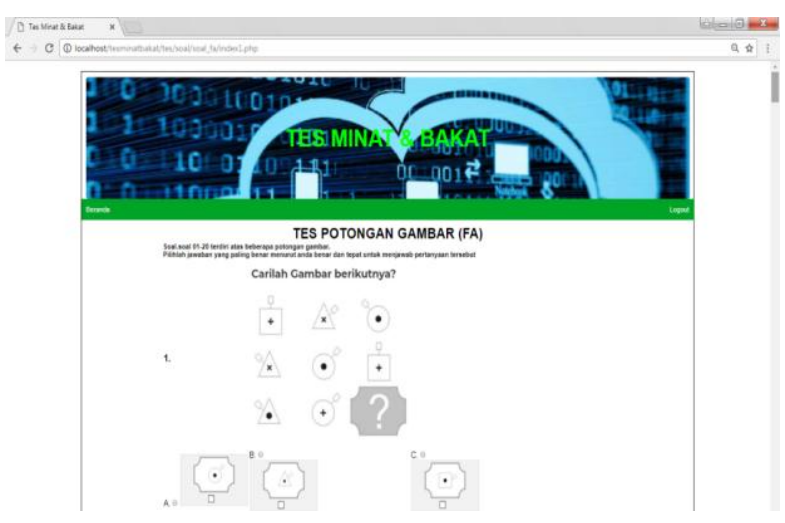

Gambar 11. Halaman Tes Soal Gambar
Petunjukkan penggunaan Gambar Gambar 11:

a) Mengakses Halaman User;

b) Klik tombol MULAI TES;

c) Sistem akan menampilkan halaman Tes Minat;

d) Ceklis atau pilih 3 jurusan yang anda minati lalu klik tombol MASUKKAN JAWABAN;

e) Sistem akan menampilkan pilihan anda, dan setelah itu anda mengklik tombol kembali, sistem akan menampilkan halaman Tes Minat dan Bakat;

f) Pilih Link pada tabel Soal, lalu sistem akan menampilkan halaman Tes Soal yang dipilih;

g) Setelah mengisi jawaban yang tepat menurut anda, selanjutnya klik tombol Perlihatkan Hasil Jawaban, setelah itu akan muncul nilai anda. Selanjutnya klik link Kembali untuk kembali ke halaman Tes Minat dan Bakat dan melanjutkan tes berikutnya.

\section{KESIMPULAN DAN SARAN}

Dari penelitian yang telah di lakukan, maka dapat diambil kesimpulan dan saran sebagai berikut.

\section{Kesimpulan}

a. Pembuatan aplikasi Tes Minat dan Bakat dengan konsep Decision Tree yang mengimplementasi RGFDT (Rules Generation From Decision Tree) menggunakan interface web dengan bahasa pemrograman PHP. 
Namun dari segi aplikasi yang telah dibangun, dapat memberikan gambaran umum menjalankan Tes Minat dan Bakat dengan membandingkan minat jurusan Perguruan Tinggi, dan akan menghasilkan nilai $I Q$ serta jurusan IPA atau IPS dan akan diberikan batas jenjang pendidikan yang dapat ditempuh dari hasil Tes Minat dan Bakat tersebut serta saran jurusan yang akan dipilih.

b. Implementasi Rules Generation terhadap Decision Tree penelitian tentang penentuan jurusan seseorang yang menggunakan algoritma $\mathrm{C} 4.5$ dalam mengimplementasi Rules Generation untuk Klasifikasi Data Bakat dan Minat Berdasarkan Rumpun Ilmu dengan Decision Tree belum dapat membantu mengetahui tingkat bakat seseorang, karena kekurangan dari peneliti dalam menerjemahkan konsep RGFDT tersebut.

\section{Saran}

a. Pengembangan interface sesuai kebutuhan pengembangan sistem selanjutnya dan sesuai kaidah hubungan manusia dan komputer seperti perbaikan desain dan kelengkapan fasilitas, utamanya tampilan lembar soal yang dibuat menarik dan mudah.

b. Perbaikan pada class diagram dan database sesuai dengan kebutuhan sistem. Penyimpanan data Tes Minat dan Bakat dalam database diperlukan untuk mengetahui hasil tes sebelumnya dan dapat menjadi bahan pertimbangan bagi pengguna tes. c. Pengembangan pada soal-soal Tes Minat dan Bakat yang sesuai dengan saran dari ahli psikologi, sehingga dalam menilai hasil tes dapat lebih akurat dan bagi pengguna tes dapat lebih percaya diri dengan hasil tes yang didapat.

d. Perbaikan pada metode penelitian RGFDT yang belum dapat diaplikasi dan diterapkan oleh peneliti.

e. Pengembangan untuk dibuat dalam sistem Android lebih baik lagi dan akan sangat memudahkan pengguna menggunakan aplikasi Tes Minat dan Bakat.

\section{DAFTAR PUSTAKA}

Amikom, Elearning. 2012. Situs Web. Bab 3 Algoritma C4.5. http://elearning.amikom.ac.id/index.p hp/download/materi/...ST078.../20121 008_C4.5.pdf, diakses 23 Januari 2018.

Ardi. 2010. Situs Web. Tes IST (Intelligenz Struktur Test). http://www.psychologymania.com/20 13/01/tes-ist-intelligenz-strukturtest.html, diakses 22 Januari 2018.

Chair, Miftahul, Nasution, Yuki Novia, dan Rizki, Nanda Arista. 2017. Aplikasi Klasifikasi Algoritma C4.5 (Studi Kasus Masa Studi Mahasiswa Fakultas Matematika Dan Ilmu Pengetahuan Alam Universitas Mulawarman Angkatan 2008). Samarinda: Program Studi Statistika, FMIPA, Universitas Mulawarman.

Denis, Alan. 2012. Situs Web. Sistem Penunjang Keputusan Seleksi Calon Karyawan Dengan Metode Promethee Studi Kasus Pamella Group Yogyakarta.

http://konseling.umm.ac.id/files/file/T ENTANG\%20PSIKOLOGI.pdf, diakses 16 Januari 2018. 
Hadi, Febri, Arlis, yafri, dan Hariyanto, Sugeng. 2017. Perancangan Aplikasi Pencarian Labor Dan Lokal Untuk Kuliah Pengganti Di Universitas Putra Indonesia "YPTK" Padang.. Padang: Universitas Putra Indonesia YPTK Padang.

Hidayatsyah, Mhd. Rido. 2013. Tugas Akhir. Penerapan Metode Decision Tree Dalam Pemberian Pinjaman Kepada Debitur Dengan Algoritma C4.5 (Studi Kasus : Bank Perkreditan Rakyat Syariah Berkah Dana Fadilah). Pekanbaru: Jurusan Teknik Informatika, Fakultas Sains dan Teknologi, Universitas Islam Negeri Sultan Syarif Kasim Riau Pekanbaru.

Ina, Wenefrida Tulit. 2013. Klasifikasi Data Rekam Medis Berdasarkan Kode Penyakit Internasional Menggunakan Algoritma C4.5. Kupang: Jurusan Teknik Elektro, Fakultas Sains dan Teknik, Universitas Nusa Cendana.

Nugroho, Irwin. 2011. Skripsi. Sistem Informasi Penerimaan Siswa Baru Berbasis Web Dengan PHP dan PHP. Yogyakarta: Program Studi Pendidikan Teknik Informatika, Fakultas Teknik, Universitas Negeri Yogyakarta.

Oktavia, Chaulina Alfianti, Rahmadwati, dan S, Purnomo Budi. 2015. Analisis Kinerja Algoritma C4.5 Pada Sistem Pendukung Keputusan Penentu Jenis Pelatihan.

Parid. 2014. Analisis dan Perancangan Sistem Informasi Perpustakaan Di SMA Negeri 1 Ciawigebang Kuningan. Yogyakarta: Program Studi Sistem Informasi, Sekolah Tinggi Manajemen Informatika dan Komputer AMIKOM Yogyakarta.

Peraturan Menteri Pendidikan dan Kebudayaan Republik Indonesia. 2015. Situs Web. Rumpun Ilmu Pengetahuan dan Teknologi serta Gelar Lulusan Perguruan Tinggi. http://kopertis3.or.id/v2/wpcontent/uploads/SEDirbelmawa0404E3-2-2015RumpunIlmu-

GelarLulusanPT.pdf, diakses tanggal 18 Januari 2018.

Rahmayani, Indri. 2014. Perbandingan Performansi Algoritma C4.5 dan Cart Dalam Klasifiksi Data Nilai Mahasiswa Prodi Teknik Komputer 